\title{
CHEMISTRY OF THE AROMA BOUQUET OF THE EDIBLE MUSHROOM "LEBRE" (Cortinarius lebre, BASDIOMYCOTA, AGARICALES) FROM CHILE
}

\author{
NORBERT ARNOLD ${ }^{1 *}$, GÖTZ PALFNER ${ }^{2 *}, J U ̈ R G E N ~ S C H M I D T^{l}$, \\ CHRISTINE KUHNT ${ }^{1}$ \& JOSÉ BECERRA ${ }^{2}$
}

\author{
${ }^{1}$ Leibniz Institute of Plant Biochemistry, Department of Bioorganic Chemistry, Weinberg 3, D-06120 Halle (Saale), Germany \\ ${ }^{2}$ Universidad de Concepción, Facultad de Ciencias Naturales y Oceanográficas, Departamento de Botánica, Casilla 160-C, Concepción, VIII Región, Chile
} (Received: October 11, 2011 - Accepted: July 13, 2012)

\begin{abstract}
Cortinarius lebre Garrido, a common edible mushroom from central Chile, is distinct from other Cortinarii by its strong, naphtalene-like smell. The relevant volatile compounds were detected by gas chromatography - mass spectrometry and identified as indole together with 1-octen-3-ol, octane-3-one, and octan-3-ol.
\end{abstract}

Key words: Cortinarius, indole, 1-octen-3-ol, volatile compounds, scent.

\section{INTRODUCTION}

Cortinarius (Cortinariaceae, Agaricales, Basidiomycota) is the most diverse genus of ectomycorrhizal fungi in South American Nothofagus forests, with more than 250 species described to date (Moser \& Horak 1975, Garrido 1988, Garnica et al. 2002). Cortinarius lebre Garrido is especially frequent in southern central Chile, where it is mainly associated to $N$. obliqua, but also grows beneath $N$. antarctica, $N$. alessandrii, N. dombeyi and $N$. glauca (Garrido 1988, pers. obs.). The epithet refers to the native Chilean name of this edible mushroom: "Lebre" can be encountered in large numbers in remnants of native forest along the coastal mountain range ("Cordillera de la Costa"), especially in the Biobío Region ( $36^{\circ} 00^{\prime}-38^{\circ} 30^{\prime}$ s. 1 . approx.) during the rainy season which usually lasts from May to August. Major quantities are occasionally sold fresh on markets in regional urban centers like Angol, Nacimiento or Concepción. The most conspicuous property of C. lebre, apart from its tough consistence and violet - colored pileus, is its pungent and unpleasant smell of camphor and moth balls (naphthalene) which can often be perceived at several meters distance from the basidiomes and which has been described by other authors like gaseous fuel or Tuber magnatum (Garrido 1988), as well as reminding of "rabbit burrow" (Valenzuela \& Moreno 1997). In an earlier description of Rozites violacea Horak (Moser \& Horak 1975) from Argentina which is probably the same species, the authors described the smell as "strongly adstringent". As to our knowledge, this very characteristic smell is not known for any other Cortinarius species, we analyzed its chemical composition using headspace gas chromatography-mass spectrometry (GCMS) for the identification of the compounds, which are responsible for the strong aroma bouquet of C. lebre.

\section{EXPERIMENTAL}

\section{Fungal Material}

Cortinarius lebre Garrido (fig. 1) was collected in Chile, VIII Región del Bio Bío, Concepción, Universidad de Concepción, La Cantera y El Guindo, $36^{\circ} 50^{\prime} 13^{\prime \prime} / 73^{\circ} 01^{\prime} 28^{\prime \prime}$ s. $1 ., 160$ m.a.s.l., remnant of mixed native forest, dominated by Nothofagus obliqua (Mirb.) Oerst. and Aextoxicon punctatum Ruiz \& Pav., on soil and litter beneath N. obliqua, 25-V-2011, CONC-F0781, leg. et det. N. Arnold, W. Helfer, G. Palfner. Voucher specimens are deposited in the Herbarium of Concepción University (CONC-F).

\section{Extraction}

Fresh collected fungal fruiting bodies (100 gr) were carefully removed from the substrate, crushed, and extracted with n-hexane $(200 \mathrm{~mL})$. After extraction, the light yellow coloured solution was evaporated at room temperature to $5 \mathrm{~mL}$ under slightly reduced pressure and exhibited further a strong gaseous fuel-like smell. This solution was immediately investigated by GC-MS. Commercially available indole (Acros) and 1-octen-3-ol (Fluka) were used as reference substances.

\section{GC-MS Analysis}

The static headspace GC-EIMS measurements were performed on a QP2010 Ultra (Shimadzu Corporation, Kyoto, Japan) by using the following conditions: electron energy $70 \mathrm{eV}$, detected mass range $\mathrm{m} / \mathrm{z} 50-500$; source temperature $200^{\circ} \mathrm{C}$; column: ZB-5MS (Phenomenex, $30 \mathrm{~m} \times 0.25 \mathrm{~mm}, 0.25$ $\mu \mathrm{m}$ film thickness), injector temperature $220^{\circ} \mathrm{C}$, interface temperature $300^{\circ} \mathrm{C}$, carrier gas Helium, column flow $1.02 \mathrm{ml} / \mathrm{min}$, constant flow mode, column temperature program: $40{ }^{\circ} \mathrm{C}$ for $1 \mathrm{~min}$, then raised to $300{ }^{\circ} \mathrm{C}$ at a rate of 10 ${ }^{\circ} \mathrm{C}$ min-1 and then held on $300{ }^{\circ} \mathrm{C}$ for 5 min. Static headspace conditions: split injection (split ratio 1:5), incubation temperature $40{ }^{\circ} \mathrm{C}$; incubation time $30 \mathrm{~min}$; syringe temperature $45^{\circ} \mathrm{C}$; injection volume $500 \mu$ l. The relative composition of the main components 1-4 were calculated from the peak areas of the total ion chromatogram (TIC).

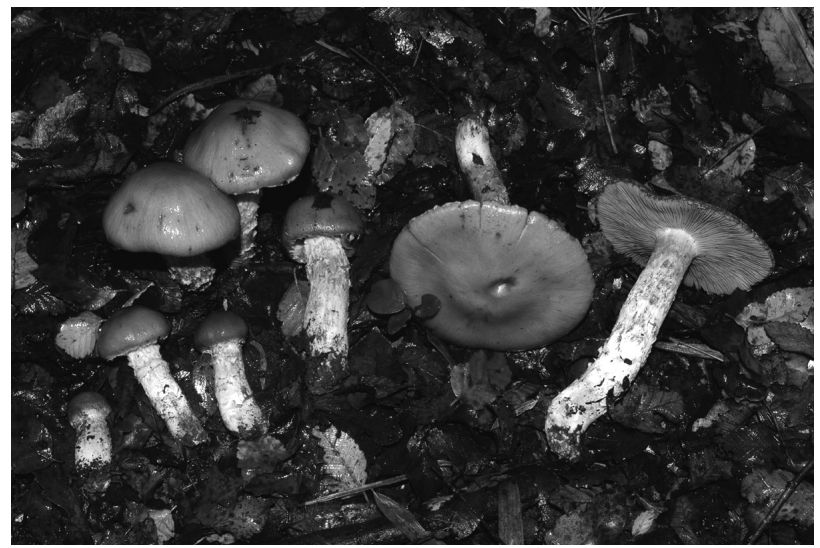

Figure 1: Cortinarius lebre in situ (CONC-F0781).

\section{RESULTS AND DISCUSSION}

A GC-EIMS analysis of the crude $n$-hexane extract from $C$. lebre demonstrates, that a mixture of indole $(\mathbf{1}, 29.3 \%$ of identified compounds, RT $29.3 \mathrm{~min}$ ), 1-octen-3-ol (2, 43.2\% of identified compounds, RT $7.23 \mathrm{~min}$ ), together with octane-3-one (3,18.7\% of identified compounds, RT $18.7 \mathrm{~min})$ and octan-3-ol (4, 8.7\% of identified compounds, RT $8.7 \mathrm{~min})$ are responsible for the gaseous fuel-like or camphor and moth balls-like odour of C. lebre. Compounds 1-4 were identified by comparison of the obtained EI mass spectra with those in the NIST 08 database.
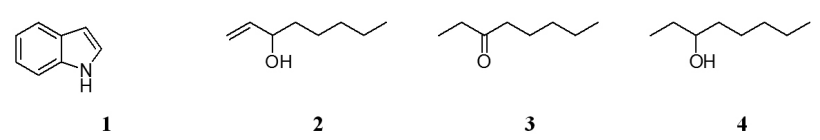

Indole (1) and indole derivatives are widespread-occurring natural products. Indole (1) can be produced by bacteria as a degradation product of the amino acid tryptophan. It also occurs naturally in human feces and has an intense fecal odour. However, it has a flowery smell at very low concentrations 
and is a constituent of many flower scents. It was isolated from etheric oils of various plants like the jasmines and orange blossoms. Hesse (1904) isolated $2.5 \%$ from jasmine, while $0.1 \%$ indole (1) was obtained from orange-blossom (Hesse \& Zeitschel, 1902). This ambiguous behaviour, with a large whiff of indole (1) smelling putrid, whereas a trace of the same chemical smells flowery, may be explained by the fact that large amounts of the chemical bind to a wider variety of receptors than do small amounts of the same chemical (Leffingwell, 1999). This olfactory ambiguity may explain why the odor of Rozites purpurea, probably conspecific with C. lebre, was described as flowery, reminding of hyacinths by the author (Moser \& Horak 1975) and is also mentioned in literature for toadstools of Tricholoma lascivum, T. inamoenum, and T. caligatum (Fons et al., 2006). The complex odor is described with a fruity sweet note (jasmine, seringa), followed by a nauseous insecticidal or sulphurated note.

Although rare in Cortinariaceae, indole (1) and its derivatives are common components of fungal scents. In some mushrooms, indole (1) is present in a mixture along with other constituents, especially 1-octen-3-ol (2, also known as mushroom alcohol), the main compound being responsible for their unpleasant odour (Table 1).

In the volatile fraction of $T$. caligatum, high levels of indole derivatives together with methyl-(E)-cinnamate, benzaldehyde and (E) nerolidol were found and are responsible for the second nauseous note of this species (Fons et al., 2006). Additionally, in some other species skatole (5) and 3-chloroindole (7) smelling fecal-like (Wood et al. 2003), respectively like coal-tar or gas-like $(\mathbf{5 , 6 , 7 )}$ (Hilber 1968; Rapior et al., 1998), can be obtained.<smiles>[R]c1c[nH]c2ccccc12</smiles><smiles>Clc1c[nH]c2ccccc12</smiles><smiles>[R]c1ccc2[nH]c(C)cc2c1[R]</smiles>
5: $\mathrm{R}^{1}=\mathrm{CH}_{3}$
6: $\mathrm{R}^{1}=\mathrm{CHO}$

7
8: $\quad \mathrm{R}^{1}=\mathrm{CH}_{3} ; \mathrm{R}^{2}=\mathrm{H}$
9: $\quad \mathrm{R}^{1}=\mathrm{CH}_{2} \mathrm{OH} ; \mathrm{R}^{2}=\mathrm{H}$
10: $\quad \mathrm{R}^{1}=\mathrm{CH}_{3} ; \mathrm{R}^{2}=\mathrm{OCH}_{3}$
11: $\mathrm{R}^{1}=\mathrm{CH}_{2} \mathrm{OCH}_{3} ; \mathrm{R}^{2}=$
$\mathrm{H}$
12: $\quad \mathrm{R}^{1}=\mathrm{CH}_{2} \mathrm{OCH}_{3} ; \mathrm{R}^{2}=$
$\mathrm{OCH}_{3}$

An overview of the so-far known occurrence of indole (1) and indole derivatives from volatile fraction of mushrooms is given in Table 1 .

Table 1: Occurrence of indole derivatives in the volatile fraction of mushrooms constituting the unpleasant scent of certain mushrooms: $1 H$-indole (1), 3-methyl-1H-indole (skatole) (5), 3-formyl-1H-indole (6), 3-chloro-1 $H$-indole (7), 2,4-dimethyl-1 $H$-indole (8), 4-hydroxymethyl-2-methyl-1 $H$-indole (9), 5-methoxy-2,4-dimethyl-1 $H$-indole (10), 4-methoxymethyl-2-methyl-1 $H$-indole (11), 4-methoxymethyl-5-methoxy-1 $H$-indole (12).

\begin{tabular}{|c|c|c|c|c|c|c|c|c|c|c|}
\hline Species & 1 & 5 & 6 & 7 & 8 & 9 & 10 & 11 & 12 & References \\
\hline Boletus calopus & + & - & - & - & - & - & - & - & - & Rapior et al. (1997) \\
\hline Gyrophragmium dunalii & + & - & - & - & - & - & - & - & - & Rapior et al. (2000) \\
\hline Morchella conica & + & - & - & - & - & - & - & - & - & Audouin et al. (1989) \\
\hline Lepiota bucknallii & + & - & - & - & - & - & - & - & - & Hilber (1968) \\
\hline Hebeloma radicosum & + & - & - & - & - & - & - & - & - & Fons et al. (2006) \\
\hline Tricholoma bufonium & + & - & - & - & - & - & - & - & - & Hilber (1968) \\
\hline Tricholoma inamoenum & + & + & - & - & - & - & - & - & - & $\begin{array}{l}\text { Hilber (1968), } \\
\text { Watson et al. (1986) }\end{array}$ \\
\hline T. lascivum & + & + & - & - & - & - & - & - & - & $\begin{array}{l}\text { Hilber (1968) } \\
\text { Eizenhöfer et al. (1990) }\end{array}$ \\
\hline T. sulphureum & + & + & + & - & - & - & - & - & - & $\begin{array}{l}\text { Hilber (1968) } \\
\text { Rapior et al. (1998) } \\
\text { Rapior et al. (2000) }\end{array}$ \\
\hline T. sciodes & - & - & - & - & + & + & + & + & - & $\begin{array}{l}\text { Garlaschelli et al. (1994) } \\
\text { Pang \& Sterner (1996) }\end{array}$ \\
\hline T. virgatum & - & - & - & - & + & + & - & + & - & Garlaschelli et al. (1994) \\
\hline T. caligatum & - & - & - & - & + & - & + & + & + & Fons et al. (2006) \\
\hline Coprinus picaceus & + & + & - & - & - & - & - & - & - & Laatsch \& Matthies (1992) \\
\hline $\begin{array}{l}\text { Hygrophorus } \\
\text { paupertinus }\end{array}$ & + & - & - & - & - & - & - & - & - & Wood et al. (2003) \\
\hline $\begin{array}{l}\text { Scytinostroma } \\
\text { portentosum }\end{array}$ & + & - & - & + & - & - & - & - & - & Arnold et al. (2007) \\
\hline
\end{tabular}

Besides their function as odorous compounds, monomeric indole derivatives as well as unstable pungent and non-pungent bisindolic derivatives are contributing to the taste of some mushrooms, especially species in Tricholoma and Collybia (Sterner, 1994; Pang \& Sterner, 1994; Pang \& Sterner, 1996; Fons et al., 2006).

Lascivol, the bitter principle of Tricholoma lascivum, degrades to dimethyl L-glutamate and 5-methoxy-2,4-dimethylindole (9) by acid methanolysis (Eizenhöfer et al., 1990). The latter compound was also isolated from $T$. sciodes and $T$. virgatum, two species which are characterized by their bitter and acrid taste (Garlaschelli et al., 1994), and from T. caligatum (Fons et al., 2006).

In pure state, indole (1) is a colourless crystalline solid, which melts at 52 ${ }^{\circ} \mathrm{C}$. It is volatile with steam and soluble in hot water. This may be the reason that $C$. lebre is favored as an excellent edible mushroom after cooking in water and discarding the broth, which reduces the content of the unpleasant indole (1). 


\section{ACKNOWLEDGEMENTS}

N. Arnold and G. Palfner acknowledge financial support by the program ALECHILE, project PCCI 2008-147, bilaterally financed by the German Academic Exchange Service (DAAD) and the Comision Nacional de Investigation Cientifica y Technologica (CONICYT), J. Becerra acknowledges support by FONDECYT project no. 1110656. We also thank Mrs. Nicole Hünecke for technical assistance.

\section{REFERENCES}

1. N. Arnold, J. Schmidt, C. Kuhnt, L. Wessjohann, L. Svensk Mykologisk Tidskrift 28, 49, (2007).

2. P. Audouin, J.P. Vidal, H. Richard, Sci. Aliments 9, 185, (1989).

3. T. Eizenhöfer, B. Fugmann, W.S. Sheldrick, B. Steffan, W. Steglich, Liebigs Ann. Chem. 11, 1115, (1990).

4. F. Fons, S. Rapior, A. Fruchier, P. Saviuc, J.M. Bessière, Mycologie 27, 45, (2006).

5. L. Garlaschelli, Z. Pang, O. Sterner, G. Vidari, Tetrahedron 50, 3571, (1994).

6. S. Garnica, M. Weiss, F. Oberwinkler, Mycologia 94, 136, (2002).

7. N. Garrido, Mykorrhizen in den Nothofagus-Wäldern Mittelchiles. Bibliotheca Mycologica 120, J. Cramer, Berlin -Stuttgart, (1988).
8. A. Hesse, O. Zeitschel, J. Prakt. Chem. 66, 481, (1902).

9. A. Hesse, Ber. Dtsch. Chem Ges. 37, 1457, (1904).

10. O. Hilber, Z. Pilzk.. 34, 153, (1968).

11. H. Laatsch, L. Matthies, Mycologia 84, 264, (1992).

12. J.C. Leffingwell, http://www.leffingwell.com/ olfaction.htm, (2011).

13. M. Moser, E. Horak, I. Gruber, Cortinarius Fr. und nahe verwandte Gattungen in Südamerika. Beih. Nova Hedwigia 52, J. Cramer, Berlin \& Stuttgart, (1975)

14. Z. Pang, O. Sterner, J. Nat. Prod. 57, 852, (1994).

15. Z. Pang, O. Sterner, Acta Chem. Scand. 50, 303, (1996).

16. U. Peintner, E. Horak, M. Moser, R. Vilgalys, Mycotaxon 83, 447, (2002).

17. S. Rapior, Breheret, T. Talou, Y. Pélissier, M. Milhau, J.M. Bessière, Cryptogamie, Mycologie 19, 15, (1998).

18. S. Rapior, C. Marion, Y. Pelissier, J.M. Bessiere, J. Essential Oil. Res. 9, 231 (1997).

19. S. Rapior, M.J. Mauruc, J. Guinberteau, C.L. Masson, J.M. Bessiere, Mycologia 92, 1043, (2000).

20. O. Sterner, Nat. Prod. Lett. 4, 9, (1994).

21. E. Valenzuela, G. Moreno, Chile. Boletin Micológico 12, 107, (1997).

22. R.L. Watson, D.L. Largent, W.F. Wood, Mycologia 78, 965, (1986).

23. W.F. Wood, J. Smith, K. Wayman, D.L. Largent, Mycologia 95, 807, (2003). 